\title{
Down the Slant towards the Eye: Hopkins and Ecological Perception
}

\author{
DANIEL WILLIAMS (D)
}

W HAT do the materials of poetry offer to our imagination of ecological change? Do the conventions of nature poems (say, of pastoral, georgic, or locodescriptive verse) reach beyond a given sociopolitical situation to convey insights for the present? Can poetic genres such as the pleasant scene or the lament over a damaged landscape be read otherwise than as nostalgic for a "nature" free from the eroding pressure of human beings? How might formal and metrical qualities signify in ecological terms? Poetic observation hones what I will refer to as "ecological perception," a way of understanding perception as involving a dynamic interaction between human bodies and the givens or potentialities of our environments, whether we characterize these as belonging to the natural world or to surroundings largely manufactured by us. ${ }^{1}$ Poetry alerts us to what different environments make feasible. It brings into direct view what might otherwise seem invisible or abstract, and it renders tangible our dependence on, and responsibility for, the media that environ us and make varieties of perception and action possible in the first place.

In this essay I offer an account of Gerard Manley Hopkins's poetry as evincing such ecological perception, particularly in its attention to how the entities and ambient properties of an environment impinge on the bodies of human observers. Hopkins drew repeated analogies between the vulnerability of natural entities and the fragility of our bodies, especially our organs of perception. Yet in collapsing the distance between these analogical domains in ways that underscore ecological perception, his journals and poems instantiate an awareness predicated not simply on the fragile beholder in and of vulnerable nature, but on more porous relations among perceiving bodies, environing surfaces or media, and the materials of poetic sense-making. Hopkins is acutely receptive to

\footnotetext{
Daniel Williams is an assistant professor of literature at Bard College. He works on nineteenth-century British and contemporary South African literature. His current book manuscript explores uncertainty in the nineteenth-century British novel in the context of developments in science, philosophy, and the law. He is also at work on a second project about weather, climate, and social representation in the nineteenth century and is coediting a special issue of Poetics Today on "Logic and Literary Form."
} 
the objects and qualities of the natural environment that appeal to our perception and that disclose what they make possible, including what they make available for poetry.

In the first section, I link Hopkins's syncretic ideas about perception to the twentieth-century psychologist J. J. Gibson's account of our sensitivity to the "affordances"-the open-ended opportunities-of specific environments. In three subsequent sections, I assess different scales of ecological perception, so redefined, in Hopkins's poetry: the limited perspective that circumscribes an elegy for a landscape bereft of its trees; the expansive reach of a conceit poem that links individual beholders to the encircling sky; and the revelatory vision of prophetic poems. Across these scales-arboreal, atmospheric, apocalyptic-we see the descriptive and affective range of ecological perception. Most apposite for our experience of environmental crisis at the intermediate scale of the atmospheric is an eerily relevant poem about the sky, discussed in the third section, that recognizes the "teleconnections" bridging global systems and specific sites. Here, Hopkins strikes a balance without remaining overly rooted to the local or bioregional (the arboreal), on one side, or rushing to a vantage entirely beyond the confines of the planet (the apocalyptic), on the other.

Bringing ecocritical scholarship on Hopkins into dialogue with work on embodied perception, I show that his poetry is responsive to ecological affordances in its formal, figurative, and metrical properties as well as in its thematic invocation of "earth," "country," "nature," or "wilderness." My contribution to this issue thus underscores the openness of ecology in two senses: the relative permeability of bodies as they perceive and navigate environments in flux; and the unbounded potentiality of the affordances presented by such environments. Poetic form appears as the site where permeability and potentiality are vividly recorded, ecological perception sharpened, and precarious interdependence registered.

\section{Interesting the Eye: Poetry and the Theory of Affordances}

Across his poetry, journals, and letters, Hopkins relies on different explanations for the functioning of visual perception. These views, drawing on classical and contemporaneous discourses about optics, underwrite what I see as his "ecological perception." On its face, this term could be understood as infusing ecological awareness into literary-cultural objects, akin to what John Parham has described as Hopkins's "ecological mode of perception," Elizabeth Miller more broadly as "ecological realism," and 
Nathan Hensley and Philip Steer still more broadly as "ecological form." "2 Yet in using this term I also bring to bear the "ecological approach to visual perception" espoused by J. J. Gibson, decades after Hopkins, in the context of psychological science. Gibson coined the term "affordance" to capture how humans and other animals see, directly and intuitively, what their environment makes possible. In this section I read Gibson's work for its uncanny kinship with Hopkins's ideas about the dynamic connection between beholder and world, and for its emphasis on how the mere perception of our environment is not value-neutral but entails relations of contact, dependence, and responsibility. Gibson's affordance theory can illuminate Hopkins's often-cryptic formulations about perception, imagination, and form in poetry: "What you look hard at seems to look hard . . a at you."

At the outset, it is important to note that Gibson's account of perception is, in philosophical terms, a sort of direct realism: the activity of perception is not mediated by mental representations or ideas, and what it finds in or draws out of the world is taken really to exist there. This model of "direct perception" emerges from experiments conducted by J. J. and Eleanor Gibson on visual cues and optical illusions, and from phenomenological reflections on how animals perceive the environment to be saturated with information for navigation and action. "Perception," Gibson writes, "is not a response to a stimulus but an act of information pickup," and it involves an immediately apprehended distinction among "substances," "media," and their contact points or "surfaces," each bearing a "characteristic texture, reflectance, and layout" (56-57, 16-32, 307). Beyond retinal data registered by the eye at a fixed point, perception is a matter of appraising our surroundings and detecting changes through motion and stasis (of the eyes, head, and body) as we take in the "ambient optic array." Perception discloses meaningful features of the environment's "layout": terrain, objects, tools, and animals. ${ }^{6}$ The latter include us and our "human displays": any "surface that has been shaped or processed so as to exhibit information for more than just the surface itself" (42).

Any environmental feature can present "affordances," which Gibson defines as "possibilities or opportunities," ways of actively "see[ing] what things are good for" $(18-19,1) .7$ "An open environment," for instance, "affords locomotion in any direction over the ground, whereas a cluttered environment affords locomotion only at openings," so a "path must afford footing" whereas an "obstacle . . . affords collision and possible injury" (36; emphasis original). The forms of a given ecological layout, in 
other words, are always issuing invitations or instructions to perceiving bodies-ways of reading, acting, and navigating. Perception for Gibson is "a style of tactile engagement rather than optical remove." 8 As such, his theory slots into what Jonathan Kramnick has identified as an "antirepresentational" lineage-from eighteenth-century thinkers like Thomas Reid to current philosophers like Alva Noë-in which perception's "active, embodied, or haptic" character is essential $(315,317)$. The "aesthetics of presence" implied in such accounts has important precursors in locodescriptive poetry, Kramnick observes, where perceiver and scene might be brought into direct and holistic relation, and objects become "features of an ecology that change with the position from which they are held" $(315,321){ }^{9}$

Since we are now more alert to what literary and aesthetic forms "afford," following the work of Caroline Levine and Terence Cave, it might be useful to recall the original aim of this concept: to convey how perceptual systems depend on ecological settings and are responsive to informative particulars and potentialities lodged therein. ${ }^{10}$ If affordances-from natural layouts to atmospheric phenomena to human displays -are inherently meaning- or value-laden properties that we prereflectively notice in our surroundings, this further requires us to recognize an undertow of ecological situatedness in any claim about the portability of formal affordances across space and time (Levine) or the cognitive utility of literary language, convention, and genre (Cave). ${ }^{11}$ The realism (philosophically speaking) of affordances-the fact that perceivers respond to opportunities that exist latently outside them-might even tacitly motivate Levine's emphasis on form's ability to travel and endure (although her account does not make such a commitment explicit). Whatever the conceptual genealogy of Levine's work, it remains crucial to see that if literary-cultural forms have affordances, these are fundamentally bound up with, and should not be abruptly disengaged from, their ecological setting-from the properties of an ambient optic array that we apprehend as embodied beings in continual motion and stasis across the earth's surface.

Hopkins's fascination with perceptual phenomena could be interpreted along these lines: he understands that the environment affords poetry. Thus he construes the objects and properties of the natural world as lending support for-as affording-poetic description, aesthetic wonder, scientific inquiry, and sacramental appreciation. His riddling language marks a genuine attempt to record aesthetic and perceptual entanglements underwritten by the shifting presentations—-the affordances—of 
ecological settings. His journal observations and poetic images are the products of a mobile body alert to details of illumination, reflectance, texture, occlusion, and parallax. He revels moreover in our environing medium's "intrinsic polarity of up and down" (Gibson, 18) and carries that quality into form, often through figures that collapse different scales ("Thrush's eggs look little low heavens"). ${ }^{12}$ Lastly, his body is alert to rhythm and repetition, to the flow of natural patterns that he subsequently transposes into "numbers": idiosyncratic metrical arrangements, verse forms, diacritical marks, and typographical layouts. ${ }^{13}$ Although the resulting formalizations are sometimes abstract or opaque in their attempt to convey a sense of indiscernible processes (e.g., seasonality) or metaphysical constructs (e.g., divinity), they still reflect ecological affordances that were once concretely perceptible by Hopkins's senses and that he is trying to make us see.

Indeed, Hopkins's central aesthetic concepts could be recast as elements of this affordance theory of poetry: "inscape" (the particular form or pattern displayed at some moment by a person, object, or scene, embodying its peculiarity, its distinction from others) and "instress" (at once the force underlying and sustaining such forms, and the perceptual activity that opens them to beholders). ${ }^{14}$ In line with the account of ecological perception sketched above, inscape and instress traverse the boundary between subjective and objective-an organizing principle of the study of vision from the nineteenth century onward-to describe how we apprehend some distinctive form, property, or pattern by grasping, as it were activating, the potentiality that undergirds it. ${ }^{15}$ So, "all things are upheld by instress and are meaningless without it," Hopkins writes, but acts of recognition are needed for the disclosure of such meaning. ${ }^{16}$ "Unless you refresh the mind from time to time," he observes, "you cannot always remember or believe how deep the inscape in things ... is" (Diaries, Journals, and Notebooks, 504). Affordances, to return to Gibson's language, are objectively "invariant," "always there to be perceived," yet subjectively "unlimited": the environment persists, "specified in the structure of the light that reaches us, but it is entirely up to us to perceive it," to take up its open possibilities (139, 128, 63; emphasis original). "These things, these things were here," as Hopkins muses in a poem about the Welsh landscape, "and but the beholder / Wánting" ("Hurrahing in Harvest," 11. 11-12).

If it is a truism that literary scholars are often worried about the disjunction between word and world, an affordance theory of poetry allows for a more direct link between these poles, a connection guaranteed 
through perceptual acts that are sustained by, and trained on, the environment's properties. Catching ecological affordances, we participate in the dual concept of instress: at once the process of our mental and perceptual effort, and the really existing principle that sustains such an effort. In his undergraduate notes on the ontology of Parmenides, Hopkins cryptically calls these poles "the foredrawing act" and "the foredrawn": the latter is what the world "offers ... to the eye" and to our other perceptual organs, disclosing a "bridge" or "stem of stress between us and things to bear us out and carry the mind over." 17 There are both practical and aesthetic aspects to these affordances. Trees offer shelter and sustenance but also formal shapes and optical patterns. Clouds give shade and rain but also models of kinesis and metamorphosis. Hopkins will sometimes privilege one set of affordances over another: he despairs at Oxford dons who cut down a birch (to increase the light afforded by their college windows) when he would rather savor the tree's beauty. ${ }^{18}$ Often his attempts to capture aesthetic affordances in language balance perceiving and making with a properly ecological consciousness. Hopkins's observations attend to what trees and mountains and skies are good for-what they make possible for us, which poetic forms they enable-while recognizing the existential fragility of our interdependence with them. ${ }^{19}$

The infrastructure of ecological perception also inflects Hopkins's syncretic understanding of how vision operates. Several scholars have noted how he creatively repurposes classical ideas about sight and evinces a wide-ranging fascination with optical phenomena and visual culture. ${ }^{20}$ Hopkins's studies in Greek literature and philosophy would have opened him to the notion of a "visual fire" emanating from the eyes and bouncing back from objects. ${ }^{21}$ Referring to the Timaeus, Catherine Phillips notes Hopkins's familiarity with Plato's articulation of this "extramission" concept, where beams emitted by the eyes merge with those produced by the sun, registering objects through "the tactile bonding of perceiver and object perceived." ${ }^{22}$ In Oxford notes on the Theaetetus, Hopkins summarizes Plato's account: "eyes, ears ... do not immediately reach the object. A wave he says comes fr. the subject, another fr. the object, and the mingling is what we feel," whereas "the ideas we know immediately." ${ }^{23}$ Phillips also floats Hopkins's acquaintance with Aristotle's "intromission" account, which advanced a translucent medium for vision, and with the different visual theories of Euclid and Augustine. ${ }^{24}$

For my purposes, the value of these views-whatever their influence on poetic imagery and form-lies in the underlying assumption that 
simply to perceive is to become entangled with objects and intervening media, to discern the affordances of light and layout. Implicitly modeling a theory of affordances, Hopkins furnishes descriptions of beholding wherein perceptual organs "catch" or are "caught by" what the environment proffers as they are enmeshed with its objects, textures, and patterns (Diaries, Journals, and Notebooks, 444, 447). Two connected poems about light sources clarify how such ensembles cross barriers between persons and things, exposing the beholder to the world's affordances in a version of what has been called "trans-corporeality." "The Lantern Out of Doors" depicts passersby who "rain against our muchthick and marsh air / Rich beams" (ll. 7-8). In a riff on the Latin root inter-esse (to be between or among), their light "interests our eyes" (1. 2), revealing the brief yet visceral yoking together of beholder and percept. "The Candle Indoors" presents the opposite scenario, as the speaker walks by a house at night:

Some candle clear burns somewhere I come by.

I muse at how its being puts blissful back

With yellowy moisture mild night's blear-all black

Or to-fro tender trambeams truckle at the eye. (ll. 1-4)

Across the mediating barrier of a "wíndow" (1. 5), the "moisture" of light implicitly calls into view our dewy perceptual membranes even as an alternative image, of tracks running back and forth between the eye and its objects, sketches a different model of visual entanglement. ${ }^{26}$

Hopkins's imagery also evokes Victorian ideas about ocular physiology and the subjective characteristics of sight. His journals ponder optical illusions and document self-reflexive experiences of seeing phenomena internal to the eye (afterimages, muscae volitantes or floaters, images on "the field of the eyelids" [Diaries, Journals, and Notebooks, 481]), perhaps alluding to the contemporaneous scientific study of such phenomena, known as "entoptics." 27 Hopkins was alert to the porousness of our sensory portals partly because he was so aware, as a matter of spiritual practice, of the dangers attendant on perceptual openness. He once observed a visual "Lent," depriving himself of the world's beauty by keeping his eyes down for months at a time. ${ }^{28}$ His early poem "The Habit of Perfection" describes a chastening of the senses to attain spiritual clarity ("Be shellèd, eyes, with double dark / And find the uncreated light"; 1l. 9-10). And Hopkins fretted throughout his life about the health of his eyes and the possibility of visual impairment and a corollary blindness of imagination. ${ }^{29}$ These cases touch on aspects and defects of "vision with 
a fixed eye or vision with a shutter" (3) that Gibson purposely ignores in order to gain a wider and more mobile field of view than the eye qua camera or screen. ${ }^{30}$ But Hopkins's concerns are in fact instances of ecological perception, and they add an undertone of vulnerability to the concept. His visual musings are responsive to what the environment conveys to a beholder, bringing the eyes, their objects, and intervening media into relation and positing the physiological fragility subtending such connections. Hopkins's reflections make clear that the eye is not a static and disembodied receptacle but a ball of flesh and fluid, open to the environment's conditions and dangers.

\section{Arbor: Perception from Root to Branch}

To approach Hopkins's work from an ecological standpoint (including here the more conventional sense of ethical responsibility for our surroundings), we need to see how his views about environmental destruction relate to poetry's formal interactions with the perceptual affordances of a given milieu. One of Hopkins's purportedly most ecological poems, "Binsey Poplars," is arguably more memorable for its emphasis on the intricacies of seeing, not seeing, and hearing. An anguished lament for an avenue of aspens near Oxford "felled 1879," as its epigraph announces, the poem works in three movements to reflect on how a beholder's subjectivity is yoked to the presentation of particular or determinate form-to "inscape." The images and formal properties of the poem assert that ecological damage is also perceptual threat. However compelling this may be as a route to ecological consciousness, the connection, I will suggest, is operative only at a limited scale.

In the poem's opening movement, the speaker's personal outcry recalls "My aspens dear" for their predominantly visual effects. The treebranches are envisioned as having "quelled, / Quélled or quenched in leaves the leaping sun" (1l. 1-2), an image of liquid containment that animates the source of light while implying a viewer who looks up through easeful "airy cages" (1. 1). Hopkins makes frequent use of images where a lattice of trees frames a beholder's vision, and more generally of figures yoking arboreal form to bodily understructure. A journal observation about elm trees after a snowstorm underlines, while personifying its objects, the vital link between beholder and inscape: "from underneath," Hopkins writes, "you saw every wave in every twig (become by this the wire-like stem to a finger of snow) and to the hangers and flying sprays it restored, to the eye, the inscapes they had lost" (Diaries, Journals, and 
Notebooks, 484-85). The trees' particular form is reanimated precisely as branches and twigs become extended participants in Hopkins's visual cognition, as if they are hands held up to the sky. What he elsewhere calls the "skeleton inscape" of trees is routinely seen against the sky or another light source (Diaries, Journals, and Notebooks, 490). Some poems extend these analogies between tree and beholding eye. An early fragment finds the "highest sprays" of ash trees "drawn as fine as lashes" ("Richard," fragment [e], 1. 6). A later, denser image sees the same branches "in clammyish läshtender cômbs créep / Apárt wìde and newnestle at héaven most hígh" ([“Ashboughs"], 1l. 5-6). Hopkins elsewhere likens trees to poetic form as such: "Below a little timber bridge I looked at some delicate flying shafted ashes-there was one especially of single sonnet-like inscape-between which the sun sent . . . beams down the slant towards the eye" (Diaries, Journals, and Notebooks, 603). Fell a tree, such images imply, and you disfigure a person, blind an eye, wreck a sonnet. Hopkins's letter reporting the scene depicted in "Binsey Poplars" confirms this deep connection between human and tree, in a significant contraction noting how the "aspens ... are everyone felled." 31

The poem goes further than this, in its next movement deploying a plural exhortation to draw an alarming analogy between "whát we do" (1. 9) in despoiling the natural world and our irrecoverable loss of sight and selfhood:

Since Country is so tender

To tóuch, her béing só slénder,

That, like this sleek and seeing ball

But a prick will make no eye at all ... (1l. 12-15)

Clearly, the affordances of light, movement, and pattern on offer at the beginning would be vitiated by such a macabre event. The structure of this segment also serves to underscore the mutual reliance of beholder and inscape in less extreme terms, bracketing the analogy between felled trees and pierced eyeballs within a long chiasmus: "Whén we delve or hew-," "Whén we hew or delve" $(11.10,18)$. In a letter months before his death, Hopkins reflects on a word cognate with "inscape," noting that "to shape ... means ^ ${ }^{\wedge}$ in old English^ ${ }^{\wedge}$ to hew," going on to observe how "life and living things are not naturally said to be hewn: they grow." 32 The actions here described-"Whén we delve or hew- / Háck and rack the growing green!" (1l. 10-11)—are inimical to life and perception. The bold, often percussive verbs- "delve" (in its earliest sense: to dig, to turn over with a spade), "hew," "hack," "rack"-underscore the force of an 
analogized breach of natural entities and human membranes, while looking ahead to the poem's acoustic (rather than visual) close. ${ }^{33}$ Yet even as the poem "observes an unselving of the seers together with the seen," it leaves room for a vision of poetic craft where the necessary shaping, ordering, and pruning of form would be more in line with verbs like "grow" than "hack" or "delve." 34

In its final movement, "Binsey Poplars" executes a shift in temporal and perceptual frames. The impoverished vantage of "Áfter-comers" to the scene who will not be able to "guess the beauty been" (1. 19)—a category in which Hopkins at least partly belongs—is set against "ónly ten or twelve / Strókes of havoc" that originally caused the damage (1l. 20-21). Aesthetic loss is projected forward in time. The shift is from seeing to hearing, most obviously in the formal lull of the closing lines with their repeated "rural scene" (1l. 23-24), but also in the thematic allusion to a cry of war ("havoc" in its original usage) ${ }^{35}$ These are both ways to signal the sense of loss when a scene can no longer be presented to a now-deflated eye (or "I," a pun matched by the echo of "hew" and "you"). In moving from what James Joyce would later call the "ineluctable modality of the visible" to that "of the audible," Hopkins also makes a metrical point that distinguishes woodsman from wordsmith, separating actions that raze natural forms from those that confer form by means of words. ${ }^{36}$ Hence, the unmaking caused by "ten or twelve / Strokes" of a monotonous axe is contrasted with the shaping power of beats, in this poem frantically irregular in pattern and almost never consistent across lines.

From its bright celebration of the visual beauty afforded by the aspens to its echoic mourning for their loss, the poem stresses the perceptual determinants of natural destruction. Following Theodor Adorno's caustic aphorism-"The splinter in your eye is the best magnifying glass"-we might straightforwardly take "Binsey Poplars" as an elegy that sharply criticizes socio-ecological change (as do poems like "Inversnaid" and "Ribblesdale"). ${ }^{37}$ For example, the poem perhaps lodges a protest against the Great Western Railway, for whose locomotives the poplars were converted into brake shoes. ${ }^{38}$ Using this poem to open a study about British culture's nineteenth-century use of the "rural scene" - a term that "always signifies a countryside both inhabited and cultivated"-Elizabeth Helsinger connects it to the georgic tradition and argues that Hopkins's "representation of . . loss calls into being a new kind of collectivity of those who share both loss and responsibility for the rural scene of destructive cultivation." 39 "Binsey Poplars" also 
fits into a lineage of tree-felling poems going back to the early modern period, at least, and growing more vocal with intensifying deforestation, enclosure, and industrialization: his father Manley Hopkins's "The Old Trees," William Cowper's "The Poplar Field," John Clare's "To a Fallen Elm" and "Helpston Green," Charlotte Mew's "The Trees are Down," William Barnes's dialect poem "Vellèn the Tree," and Thomas Hardy's "Throwing a Tree." 40

Yet poems about fallen trees are typically local, specific, rooted-like the objects they describe. Whatever the quality of protest in such representations, their immediate radius of concern is limited in space (shelter and shade removed) and perforce truncated in time (growth cut short), pace the worry about "Áfter-comers." If tree-felling poems participate in what Elizabeth Miller has called "dendrography," a mode of representation pulling the human up into "the scale and perspective of the arboreal," there is nevertheless a clear brake on such reach. ${ }^{41}$ Hopkins does attempt to mediate between human and arboreal scales. But his lament is framed, I have suggested, as a perceptual threat that shows how the catastrophe endured is ecological because it entails the loss of our means to apprehend, to "catch" the affordances of, inscapes. The poem's analogy is thus anthropocentric at heart: it reaches up to trees and branches, pauses, and arcs back to the perceiving human body. A later poem, to which I now turn, imagines the enmeshment of bodily membranes and natural milieus in a more expansive fashion that balances both analogical poles.

\section{Atmosphere: Affordances in the Round}

"The Blessed Virgin compared to the Air we Breathe," which Hopkins wrote as a devotional exercise in 1883, is built around an analogy that spirals out into doctrinal and scientific complexities. ${ }^{42}$ As the mother of Jesus Christ, Mary plays a role in Catholic tradition as the "mediatrix," the intercessor between God and humanity. Hopkins develops an extended comparison between Mary's maternal, mediating, mercybringing role and the nurturing surround of the earth's atmosphere, its "world-mothering air" (1. 1). "I say," the poem asserts, "that we are wound / With mercy round and round / As if with air" (1l. 34-36). In this section, I consider how the poem's representations of fragile interdependence, especially as refracted through scientific ideas about light and vision, open out an ecological imaginary that bridges many scales from the minute to the massive. Shuttling between scalar extremes to 
characterize the analogical benevolence of his objects (Mary, the atmosphere) while also pondering the existential threat posed by their absence, Hopkins moves beyond the local to make representable a global vision of atmospheric dependence that also intimates the precarious state of our planet in space. By generalizing the sky's affordances as available from any vantage point-perceiving them "in the round," as it were-the poem develops ecological perception at a scale particularly germane to our awareness of environmental crisis.

Like "Binsey Poplars," "The Blessed Virgin" stresses the lifesustaining interconnection of beholders and natural scenes, and at the poem's outset its perceptual allegory provides a rich source for thinking through ecological perception as the direct entanglement of fragile entities. The air "each eyelash or hair / Girdles" (ll. 3-4) also scales down to encircle the body and its life-sustaining organs, flowing unavoidably to provide "My meal at every wink" and that which "by life's law, / My lung must draw and draw" (11. 12, 13-14). ${ }^{44}$ The opening pageant of delicate entities environed or penetrated by the atmosphere-eyes, lashes, lungs-is underlined by a flood of liquid sounds miming the air's actions ("Nestling," "Girdles," "riddles"; 1l. 2, 4, 7) as it becomes "rife / In every least thing's life" (11. 7-8). ${ }^{45}$

A nexus of scientific ideas dramatically expands the scale and, by extension, the ecological value of perception in "The Blessed Virgin." After developing the poem's basic analogy, Hopkins stakes a claim about the color of the sky and its relation to the quality of light that reaches us, through the intercession of the Marian atmosphere:

Again, look overhead

How air is azurèd;

O how! Nay do but stand

Where you can lift your hand

Skywards: rich, rich it laps

Round the four fingergaps.

Yet such a sapphire-shot,

Charged, steepèd sky will not

Stain light. Yea, mark you this:

It does no prejudice.

The glass-blue days are those

When every colour glows,

Each shape and shadow shows. (11. 73-85)

Performing the sky's inescapable surround, Mary's iconographic association with blue seeps through in ritual allusions to crystals (and perhaps prisms), to her dyed ("steepèd") blue cloak, and to panes paradoxically 
stained "glass-blue" even as they do not "Stain light." The imagery of subjective perception-light and color spilling around an outstretched hand from one perspectival location-meets a set of metaphors drawn unmistakably from optics. ${ }^{46}$

Hopkins lived at an energizing time for the scientific study of light, vision, and atmospheric phenomena, and his diaries, journals, and letters document a fascination with optical ideas and meteorological events. ${ }^{47}$ Periodicals were full of reports on experimental inquiries into reflection, refraction, diffraction, polarization, and related phenomena, further aided by the development of spectroscopy in the 1870s (of which Hopkins was aware).$^{48}$ Such experimental and theoretical work was complemented by observational science, to which endeavor Hopkins briefly contributed around the time of "The Blessed Virgin." In four letters to Nature addressed from Stonyhurst College, where he had over the years interacted with the resident observatory, Hopkins cataloged unusual optical effects in the atmosphere (especially after the eruption of Krakatoa in 1883). ${ }^{49}$ Plans for a study on "Light and Ether," mentioned in 1886, confirm his persistent interest in these materials. ${ }^{50}$

In "The Blessed Virgin," Hopkins alludes to a vivid problem in Victorian optics, as Gillian Beer was the first to observe: namely, how the "air is azurèd." The physicist John Tyndall, whom Hopkins met in the Alps in 1868, conducted a set of experiments in 1869 in which he beamed light through a tube to produce suspensions of fine particles of various substances, aiming to investigate the degree and angle of polarization of the light thereby diffracted. An incidental finding was the light-blue appearance of almost any "cloud" thus produced. ${ }^{52}$ Building on Tyndall's results and his own work on color perception, John Strutt (later Lord Rayleigh) reasoned in 1871 that the sky's blue must be related to the diffraction of sunlight by "small suspended particles which divert the light from its regular course," the degree of "scattering" varying according to the wavelength of the light's color components to produce an overall "azure." ${ }^{53}$ Blue light's shorter wavelength ensures greater "Rayleigh scattering," as we still call it. Rayleigh corrected Tyndall's position by using the terms "diffraction" and "scattering," noting that the wave theory's usual concepts of reflection and refraction were beside the point since "the particles to which the sky is supposed to owe its illumination must be smaller than the wave-length, or else the explanation of the colour breaks down." 54

Hopkins follows the lineaments of this account. He understands that the scattering process resulting in the sky's color does not alter 
(or "stain") the spectrum of visible light, incidentally taking a canonical example of indirect perception (color) and fusing it directly into the environment's ambient media. ${ }^{55}$ Beer argues for Tyndall's influence here and brings out lexical similarities between the poem and his work. ${ }^{56}$ Hopkins's vision of the sky moves well beyond questions of perceived color, however. He condenses mineral, electrical, and liquid figures ("sapphire-shot, / Charged, steepèd sky") in a manner evocative of the continuing analogical supports for understanding optics as such, in this period, by means of sonic and hydrodynamic phenomena. ${ }^{57} \mathrm{He}$ also shares a sense of the importance of perceptual sensitivity with scientific observers of the sky in the tradition of Tyndall and Rayleigh. ${ }^{58}$

In bringing more concrete details of Rayleigh's account to bear, I suggest that an additional emphasis on the intensity of light underlines the ecological import of these scientific borrowings, stressing the vital role of the atmosphere in protecting our planet from space. Hopkins praises as one benefit of the Marian atmosphere the mercifully diminished power of the light passing to earth, after accounting for what Rayleigh described as "the intensity of the light emitted laterally" (1:92):

\author{
Whereas did air not make \\ This bath of blue and slake \\ His fire, the sun would shake, \\ A blear and blinding ball \\ With blackness bound ... (11. 94-98)
}

Following the scriptural tradition that holds us unable to bear the direct sight of God, Hopkins has Mary acting as a filter for the sun: "And her hand leaves his light / Sifted to suit our sight" (1l. 112-13). The granular figure enacts a sort of sonic diffraction by keeping one set of alliterations $(h, l)$ separate from those in the next line $(s)$. As Beer notes, the image probably alludes to Tyndall, who refers to the color of "unsifted solar light" in a popular lecture; elsewhere the figure refers to air's material constituents in specifying an experimental condition where it "was so sifted as to entirely remove the visible floating matter, [and] it no longer exerted any sensible action upon the light." ${ }^{, 59}$ The unexpected ecological salience of the optical-perceptual nexus behind these lines can be brought out in contrast with "Binsey Poplars." In the earlier poem, leaves "quenched" sunlight by offering shade while undergoing photosynthesis. ${ }^{60}$ In "The Blessed Virgin," a great deal more is at stake as the sky similarly "slake[s]" incoming rays. The sky's moderated intensities of light and color, in other words, parallel its function as a protective layer 
against radiation and matter from space (a property also detailed in this period) ${ }^{61}$

Yet even though the sky's sheltering function is more existentially vital than the poplars', there is no direct apprehension of its destruction. The poem only ventures a hypothetical vision of perception without our atmosphere. The sun in such a scenario, like the eye compromised by its unfiltered intensity, would be figuratively "blear and blinding." 62 Through a theological and optical conceit moving out from an individual beholder all the way to the circumference of the earth and back, the poem posits the necessary presence of the atmosphere. As its images scale down to the level of bodily surfaces, its main conceit scales up to imagine a totality. The "seeing ball" of "Binsey Poplars" becomes a seeing globe, as it were, that prospectively shields us from the threat posed by a yet-vaster "blinding ball." Like the earlier poem, "The Blessed Virgin" addresses its natural entity with fondness ("Be thou then, O thou dear / Mother, my atmosphere"; 11. 114-15). Yet its exhortation to the beneficent air, which allows us to see and hear, emphasizes the surrounding quality of the atmosphere's affordances ("Above me, round me lie / Fronting my froward eye"; "Stir in my ears, speak there / Of God's love"; 11. 118-19, 121-22). Images of "the round air" ("The Loss of the Eurydice," 1. 65), often with protective overtones, are common in Hopkins. They typically move from local scenes (in Wales, "That cordial air made those kind people a hood / All over" ["In the Valley of the Elwy," 11. 5-6]) to global heights (where a lark hovers, "the circled earth / Spreading still its sunnèd girth" ["Il Mystico," 1l. 69-70]).

Hopkins's yet-later poems of apocalypse, to which I turn in the next section, will envision the end of the world in terms reflecting Victorian obsessions about entropy and the eventual heat death of our sun: an allconsuming fire followed by a frigid darkness when "death blots black out" ("That Nature is a Heraclitean Fire and of the comfort of the Resurrection," 1. 14). This poem's disaster ex hypothesi, by contrast, seems more concretely imaginable because the affordances it would eliminate are registered at several scales that include, and come close to, the perceiving body. Take away the atmosphere and you have a blinding and overpowering sun by "blackness bound," stars appearing to our eyes only "like flecks of coal, / Quartz-fret, or sparks of salt, / In grimy vasty vault" (1l. 100-102). It may put too much weight on this poem to point out that its inorganic and mineral imagery-"fire," "coal," "salt"-links up to a sustained critique of industrial blight in Hopkins's poems about landscapes "seared with trade; bleared, smeared, with 
toil" in "our sordid turbid time" ("God's Grandeur," 1. 6; "The Sea and the Skylark," 1. 10). But it does not go too far to see how the conceit of perceptual fragility has acquired a more pressing, because more entirely encompassing, sense of ecological import. "The Blessed Virgin" extends the scale of concern beyond the rootedness of "Binsey Poplars" while maintaining, in amplified form, the holism of an ecological perception "commensurate with the body of the observer" (Gibson, 143; emphasis removed).

The formal enactment of an analogy between perceptual flux and poetic rhythm-eyes fluttering, beats falling-writes ecological affordance into the materials of poetry. ${ }^{63}$ "The Blessed Virgin" is written in rhyming iambic trimeter (with some lines containing only two dactyls), mostly in couplets (with some triplets). Rhymes often provide a sonic thickness to images of absence or mediation, such as the light that "laps / Round the four fingergaps," or the "work [Mary] has to do- / Let all God's glory through" (1l. 29-30). Enjambments overflow the rhymed structure to enact the doubled fusion and separation that characterize atmospheric layers and optical effects ("mixed / With," "me / In," "hand / Skywards"; 11. 6-7, 69-70, 86-87). Unlike the studied irregularity of "Binsey Poplars," this poem places its observations into a metrical matrix where the rhyme and foot patterns are of the same order (two or three). This makes for a brisk pace and noticeably vertical structure spilling down the page, like the light streaming from the sky, even as the entire poem is folded into a chiasmus that mimics Mary's atmospheric embrace ("Wild air, world-mothering air," "World-mothering air, air wild"; 1l. 1, 124). The poem's key figures and alternations-eyes blinking, lungs breathing, the "beating heart" (1. 50)—are thus reflected in its rhythmic patterns, perhaps underlined by an allusion Hopkins uses in the 1880s to link the Latin word for poetic stress and the Vulgate's phrase for "in the twinkling of an eye" (both ictus). ${ }^{64}$ "The Blessed Virgin" demonstrates the salience of thinking through poetics in physiological terms, as scholars of Hopkins have recently done, but it also allows us to see such embodied representations as undergirding an ecological formalism. ${ }^{65}$ The poem's images and slanting lines of stress filter the sensible in "laps" of light and color rather than "Strokes" of an axe. Imagining the mediation of what takes place "down the slant"-the slant of both sunlight and poetic stress- "The Blessed Virgin" makes us aware of the vitality of perception for ecological thinking, holding steady a vision of environmental affordances that inseparably sustain life and poetry. 


\section{Apocalypse: Closing Ecological Perception}

Hopkins's late apocalyptic poems offer a final stage in the scalar expansion I have been tracing, but also in some sense a retreat from ecological salience. The entire earth-not just trees and clouds and skies-is here definitively annihilated, its residue sublimated into an abstract doctrine of revelation. I have argued elsewhere that these poems function as the culmination of a "poetics of order" Hopkins had been developing throughout his life ${ }^{66}$ Here I extend that line of argument to show how this apocalyptic verse furnishes a vision of destruction so total that it eschews the scalar equilibrium that, in my view, makes "The Blessed Virgin" instructive for ecological consciousness now. These poems flatten out the multifaceted affordances of Hopkins's prior environments, so meticulously described in the nature sonnets of the 1870s, and do away with the beholder as such. Yet if this apocalyptic mode marks the limit of ecological perception, the closing down of affordances, it still retrospectively underlines Hopkins's earlier emphasis on ambience and embodiment across several scales. These late poems also embody certain affective and generic temptations of Anthropocene discourse, specifically the allure of totalizing forms of elegy and lament.

"Spelt from Sibyl's Leaves" (1884), a sonnet whose shape is distended by its unusually long eight-foot lines, forecasts an "earthless" night in which humanity is left "sheathe- and shelterless," our solid ground and shielding canopy having vanished in darkness (ll. 1, 14). Hopkins collapses humanity's life-cycle at the outset, putting its stages-beginning (womb), duration (home), and end (hearse)-in appositive phrases as "Evening strains to be tíme's vást, | womb-of-all, home-of-all, hearse-of-all night" (ll. 1-2). Gone are what we might recall as the "pied" affordances of Hopkins's nature sonnets, which envisioned "without oversimplifying complexity ... the oneness of the biosphere." ${ }^{\text {" G7 }}$ Gone are those poems' perceptual cues, as earth's variegated "dápple is at énd" (1. 5). Recasting the arboreal frame of "Binsey Poplars" and his journal observations, Hopkins converts the flickering contrast between branches and sky into a severe and paradoxical black on black: the "beakleaved boughs dragonish | damask the tool-smooth bleak light; black, / Ever so black on it" (1l. 9-10). If in the earlier poem the slashing of an eye evokes the destruction of the planetary "ball," here the night that "whélms, whélms, ánd will énd us" removes the eye entirely from view (1. 8).

The displacement of the beholder as a fundamental condition of apocalypse is taken further in "That Nature is a Heraclitean Fire and 
of the comfort of the Resurrection" (1888), a similarly denatured sonnet (a coda of ten lines follows the usual fourteen) that lays out, as a logical proposition, how the chaotic flux of nature will eventually be subsumed in Christ. The poem begins in similar vein to "The Blessed Virgin," describing a system sustaining the globe: the hydrological cycle. Yet human agency and perception are merely tangential here. The subjects of the poem's opening clauses are entities within an engulfing system of energy flows: clouds ("torn tufts" and "heaven-roysterers" cavorting across the sky); wind (hastening evaporation from the muddy soil as it "beats earth bare / Of yestertempest's creases"); and trees (casting shadows "wherever an elm arches" on the remnants of human infrastructure, "roughcast" and "whitewash" walls) (1l. 1-2, 5-6, 3). In the turbulent flux Hopkins initially imagines as an ever-changing conflagration along the lines of Heraclitus's philosophy, the human aggregate is mere kindling: "Million-fuelèd, | nature's bonfire burns on" (1. 9). In this "world's wildfire" that will eventually "leave but ash" (1. 20), we are far indeed from the "world-mothering air" of "The Blessed Virgin," affording breath, vision, rhythm, and shelter. ${ }^{68}$

In tandem with "Spelt from Sibyl's Leaves," "That Nature is a Heraclitean Fire" looks first to efface all indices of human agency by setting them against the scale of elemental physical and cosmic systems, and next to sublimate our agency into a higher Christological order. Human inscription emerges at the fulcrum points of this strange sonnet in a process of radical chastening: "manmarks" (1. 8) appear only as the direct objects of natural processes at the end of the sonnet's octave; and crossing its fourteenth line we are reminded that no "mark" could be "at áll so stárk / But vastness blurs and time | beats level" (1l. 14-16). ${ }^{69}$ These formal transgressions indicate not a mediation across the body's porous surfaces but rather a setting aside of embodiment as such, in preparation for a final metamorphosis as the speaker discovers "I am all at once what Christ is" (1. 22). Hopkins clearly had gnawing personal reasons for casting these poems in an extraordinary register, opposing "the Resurrection" to "grief's gásping, | joyless days, dejection" (1. 17), just as the visceral damage felt at the scene of felled trees had occasioned a poem that ends as if by lulling a damaged body to sleep. We have arrived in the realm of dark vastness hypothesized in "The Blessed Virgin," were it not for the blue sky, but the potential ecological valence of the apocalypse is compromised by its placement entirely beyond the ordinary situations of human perception, beyond the affordances normally opened to us by our variegated environment. 


\section{Conclusion}

Hopkins's alertness to environmental fragility works through a set of figurative transfers and formal techniques that bring the precariousness of the body and its perceptual systems into alignment with natural entities. At a local or bioregional scale, "Binsey Poplars" makes clear the analogy between threats to individual beholders and their perceptual scenes. At a cosmic scale, "Spelt from Sibyl's Leaves" and "That Nature is a Heraclitean Fire" subsume the perceptual scenarios of millions of beholders into a darkness that presages a messianic light. Between these elegies that look both back and forward, to infantile recursion or imagined resurrection, "The Blessed Virgin" operates across many scales to fuse fond encomia with what could be termed subjunctive elegy. This poem celebrates our entanglement with, while warning us against the damaging alteration of, the milieu that is "rife / In every least thing's life." It is here, I have argued, that the ecological character of Hopkins's formal and figurative operations is most compelling for us now. This curious occasional poem, pinned up next to a devotional shrine by an eccentric English Jesuit in 1883, could offer something to an ecological discourse currently struggling with how to find a felt imaginary-an appropriate formal, affective, or generic response-for the slow-motion crisis of the Anthropocene. ${ }^{70}$

The theory of perceptual affordances on which I have drawn allows a consideration of poetry as an open system, responsive to what the environment unendingly makes feasible in language, rhythm, image, and figure. Yet poetry can also recursively offer affordances to ecology, making newly visible the danger of human modifications that, aiming to increase what is good for us alone, end by changing the conditions, layouts, and media of our existence. ${ }^{71}$ Hopkins helps us to think and to thicken the atmosphere as an entity of multivalent ecological concern, to formalize and make tangible the connections joining our environment to the myriad bodies that depend on its unceasing continuance.

\section{NOTES}

With gratitude to Devin Griffiths, Deanna Kreisel, Naomi Levine, and Kathryn Tabb.

1. In this respect, my account of "ecological perception" is sympathetic to what Taylor has termed the "abnatural," where nature "exists in a 
state of perpetual withdrawal" but also displays an "uncanny persistence" (Sky of Our Manufacture, 5).

2. Parham, Green Man Hopkins, 101; Miller, "Dendrography," 698; Hensley and Steer, Ecological Form.

3. Hopkins, Diaries, Journals, and Notebooks, 504. All subsequent references to this edition are noted parenthetically in the text.

4. Gibson, Ecological, 10. All subsequent references to this edition are noted parenthetically in the text.

5. On the "ambient optic array," see Gibson, Ecological, 65-92.

6. On "layout," see Gibson, Ecological, 36-43.

7. For Gibson's overview of affordances, see Ecological, 127-43.

8. Kramnick, "Aesthetics and Ecology," 317. All subsequent references to this edition are noted parenthetically in the text.

9. Kramnick's examples in "Aesthetics and Ecology" are John Dyer and James Thomson. Gibson's work has also informed art-historical views on space and depth perception (see Gombrich, "Vault of Heaven") and anthropological ideas about human dwelling in the nonhuman world (see Ingold, Being Alive, 77-79, 111-19, 126-35).

10. See Levine, Forms, 6-21; and Cave, Thinking with Literature, 46-62, 150-51. Levine cites an early version of Gibson's "Theory of Affordances" (Forms, 152n.15) while acknowledging her touchstone as design theory, where the concept denotes "the potential uses or actions latent in designs" (6). Forms as "abstract and portable organizing principles" are thus modeled more on the objects and materials of design - things capable of "bringing their affordances with them"-than on the embedded media and substances of (perceptual) ecology (Forms, 7, 8). Cave leans more on Gibson while still seeing affordances as primarily a "cognitive bridge" in the context of cultural evolution and literature's "uses as an instrument of thought" ( Thinking with Literature, 6, 55).

11. See Gibson, Ecological, 127 for the claim that "the composition and layout of surfaces constitute what they afford," which "implies that the 'values' and 'meanings' of things in the environment can be directly perceived" (emphasis original).

12. Hopkins, "Spring," 1. 3, Poetical Works. All subsequent references to this edition are noted parenthetically in the text (by poem titles and line numbers). I include Hopkins's stress marks but omit other quasimusical marks.

13. See Kitcher, Mathematical Knowledge, for a Gibson-inspired theory of another domain of "numbers" (mathematics), characterized as "an 
idealized science of operations which we can perform on objects in our environment" (12).

14. On these multivalent concepts, see Zaniello, "Sources"; Brown, Hopkins' Idealism, 67-91, 226-37; Sobolev, "Inscape Revisited"; and Cotter, "Inshape." Brown succinctly defines instress as "the universal form of determinate being, dynamic unity, which when it is embodied in perceptible matter displays certain scapes or appearances"; and inscape as the "articulation of such matter by instress," hence "a particular instance of determinate being" (Hopkins' Idealism, 236).

15. Much work in the history of vision accepts an early nineteenthcentury shift, influentially documented by Crary, Techniques of the Observer, from viewing the eye as an objective, neutral portal (like a camera obscura) to investigating its subjective, physiological characteristics. For the Victorian context of visual objectivity and subjectivity, see Flint, Victorians, 1-39; and Willis, Vision, Science, and Literature, 2-5.

16. Hopkins, Oxford Essays, 311.

17. Hopkins, Oxford Essays, 315, 313. For discussion, see Cotter, Inscape, 12-16; and Brown, Hopkins' Idealism, 161-86.

18. Hopkins, Correspondence, 1:49-50; to his mother, 19 October 1863.

19. This potentiality of affordances distinguishes my approach to nature in Hopkins from otherwise congruent interpretations: analyses of the journals as discovering "determining laws or patterns in the most intense instances of natural flux" (Brown, Hopkins' Idealism, 22) or an intuitive, preconceptual "charisma" in how natural phenomena "solicit and engage the observer's attention" (Pfau, "Rethinking the Image," 137-38); and accounts of the verse as evincing "a deep ecological poetic, designed to reconvey the phenomenological moment and to enable us to feel the rhythms and processes of nature" (Parham, Green Man Hopkins, 98).

20. See generally Phillips, Gerard Manley Hopkins; Thornton, All My Eyes See, and Dunleavy, "The Naked Eye."

21. On early Greek theories, see Smith, From Sight to Light, 23-75; and Darrigol, History of Optics, 1-11.

22. Phillips, Gerard Manley Hopkins, 252.

23. Hopkins, Oxford Essays, 240; see generally 240-41.

24. Phillips, Gerard Manley Hopkins, 252-55.

25. See Alaimo, Bodily Natures, 1-22.

26. For another juxtaposition of these poems, see Phillips, Gerard Manley Hopkins, 255-58. 
27. For examples, including discussion of this musing on "dream-images," see Phillips, Gerard Manley Hopkins, 245-48; and Dunleavy, “The Naked Eye," 11-12, 38-43. The first treatises on entoptics were Jago's Ocular Spectres and Structures (1856) and Entoptics (1864).

28. He remarks that "a penance which I was doing fr. Jan. 25 to July 25 prevented my seeing much that half-year" (Diaries, Journals, and Notebooks, 471).

29. See Phillips, Gerard Manley Hopkins, 247; and Dunleavy, “'The Naked Eye," 5-9, 12-13.

30. Among these "facts" Gibson includes "the blind spot, the entoptic phenomena, the gaps in the visual field (scotomas), the afterimages of prolonged fixation, the tests for so-called acuity, the examining of the retina with an ophthalmoscope, the symptoms of eye disease, and the prescribing of corrective spectacles" (Ecological, 3-4).

31. Hopkins, Correspondence, 1:348 (emphasis mine); to Richard Watson Dixon, 13 March 1879. On Hopkins's contextual experience of trees, forests, and deforestation, and the analogy between poets and trees, see MacKenzie, Excursions, 75-85.

32. Hopkins, Correspondence 2:968; to Robert Bridges, 19-20 October 1888.

33. Oxford English Dictionary, 2nd ed., s.v. "delve, v.," def. 1a.

34. Helsinger, Rural Scenes, 4. For more on the eye image, see MacKenzie, Excursions, 85-87.

35. Oxford English Dictionary, 2nd ed., s.v. "havoc, n."

36. Joyce, Ulysses, 31.

37. Adorno, Minima Moralia, 50. Other ecological readings of the poem include Nixon, "'Sweet especial rural scene"; Day, "Hopkins' Spiritual Ecology"; Costantini, “'Strokes of Havoc"; and Parham, Green Man Hopkins, 205-10.

38. R. Martin, Gerard Manley Hopkins, 307.

39. Helsinger, Rural Scenes, 5-6.

40. In “'Strokes of Havoc," Costantini discusses Manley Hopkins's poem and mentions Cowper and Clare. For other accounts, see Nixon, "Fathering Graces at Hampstead" (on Manley Hopkins); Bohm, "William Cowper"; Gardner, Gerard Manley Hopkins, 1:152 (on Cowper); Thornton, "Sentimental Ecology" (on Clare); and Marsden, Poems, 230-31 (on Barnes and Hardy).

41. Miller, "Dendrography," 696. 
42. For the doctrinal complexities of why Mary qua atmosphere "Mantles the guilty globe" (1. 39) see Gardner, Gerard Manley Hopkins, 1:18790; Hopkins, Poetical Works, 436-37; and Cotter, Inscape, 131-37.

43. Hopkins, Correspondence, 2:576; to Bridges, 11 May 1883.

44. Compare "The Leaden Echo and the Golden Echo": "not a hair is, not an eyelash, not the least lăsh lost; every hair / Is, hăir of the head, nümbéred" (11. 36-37). Aerial elements are elsewhere compared to parts of the eye, like clouds as "parting lids" ("A Vision of the Mermaids," 1. 11).

45. Anatomical structures surrounding the eye were essential to entoptic inquiry: on "apparitions" cast by the eye's lashes, lids, and fluids, see Jago, Entoptics, 36-51.

46. "The Wreck of the Deutschland" contains a similar image: "I kiss my hand / To the stars, ... / Kiss my hand to the dappled-with-damson west" (1l. 33-34, 37). Hopkins may be recalling William Morris's "The Defence of Guenevere": "if I had // Held out my long hand up against the blue, / And, looking on the tenderly darken'd fingers, / Thought that by rights one ought to see quite through, // There, see you, where the soft still light yet lingers, / Round by the edges" (1l. 120-25).

47. See Heuser, Shaping Vision, 9-17, 50-56; Brown, Hopkins'Idealism, 9299 (on moral aspects of perception); Phillips, Gerard Manley Hopkins, 41-86 (on drawings and natural observations), 245-63 (on theories of vision); Zaniello, Hopkins, 58-84; Banfield, "Darwinism," 177-78; and Hutchison, "Eye Rhyme."

48. See his undergraduate essay, "The Tests of a Progressive Science" (Oxford Essays, 286).

49. On these letters, see Zaniello, "Spectacular"; and Hopkins, 118-29; and Phillips, Gerard Manley Hopkins, 249-50. On Hopkins's scientific interactions at Stonyhurst, see Zaniello, Hopkins, 85-117.

50. Hopkins, Correspondence 2:798; to Dixon, 7-9 August 1886.

51. Beer, "Helmholtz," 133-35.

52. Tyndall, "On the Blue." He also discusses these topics in Six Lectures on Light (25-30).

53. Strutt, Scientific Papers, 1:87, 102. The original papers are "On the Light from the Sky, Its Polarization and Colour" and "On the Scattering of Light by Small Particles." In "Some Experiments on Colour" (1871), replicating James Clerk Maxwell's color pane experiments with different results under cloudy and blue skies, Rayleigh first wondered "whether the difference of sky and cloud light had ever been made 
the subject of direct investigation" (1:82). For an overview of this juncture in explaining the sky's color see Pesic, Sky in a Bottle, 95-118.

54. Strutt, Scientific Papers, 1:88 (emphasis original). Here Rayleigh is agnostic about the diffracting "particles." Only in "On the Transmission of Light through an Atmosphere Containing Small Particles in Suspension, and on the Origin of the Blue of the Sky" (1899) does he confirm that air molecules cause the scattering. For Rayleigh's summary views, see his Encyclopadia Britannica entries on "Optics" (1884) (Scientific Papers, 2:385-414) and "Wave Theory of Light” (1888) (3:170-76).

55. See Kramnick, "Aesthetics and Ecology," 322-23. Hopkins used a similar image in 1879: "Like blue sky, which for all its richness of colour does not stain the sunlight, though smoke and red clouds do, so God's graces come to us unchanged but all through her" (Sermons, 29). For Parham, this contrast adds "social critique" to the poem (Green Man Hopkins, 185).

56. Beer, "Helmholtz," 133-35. Others have built on Beer's account: Brown, Hopkins' Idealism, 243-46; Banfield, "Darwinism," 187-88; Dunleavy, "The Naked Eye," 36-37; and Parham, Green Man Hopkins, 182-83 (mentioning Rayleigh).

57. In "Il Mystico," the sky is similarly characterized as "liquid heaven sapphire-pale" (1. 99). Observing the lapping of seawater, Hopkins is knowledgeable about the similarity between "mechanical reflection" and "optical" (Diaries, Journals, and Notebooks, 589) and thus "restates an analogy between hydrodynamics and light that is foundational for modern optics" (Brown, Hopkins' Idealism, 204). For other parallels between "atmospheric and hydrodynamic phenomena" in Hopkins, including light and sound, see Brown, Hopkins' Idealism, 243-53. On the acoustic analogy for light emerging in the seventeenth century, see Darrigol, History of Optics, 37-39.

58. On the virtues of observation in Victorian astronomy, see Anderson, "Looking at the Sky." Rayleigh "attribute[s] the considerably greater accuracy of my observations rather to an excellent perception of minute differences of colour (to which I have always found my eyes very sensitive) than to greater care in conducting the experiments" (Scientific Papers, 1:81).

59. Beer, "Helmholtz," 134 (quoting Tyndall's "The Scientific Use of the Imagination" [1870]); Tyndall, "On the Blue," 390 (emphasis removed).

60. Parham, Green Man Hopkins, 208. 
61. By Joule, who describes "the atmosphere which covers us with a shield" as a "wonderful provision made by the Author of nature for the protection of his creatures" ("On Shooting Stars," 351).

62. Hopkins puts a scientific analogy to doctrinal ends, but a natural theology reading is conceivable: in Theology in Science (1860), Ebenezer Cobham Brewer speculated on the atmosphere's designed character (Lightman, Victorian Popularizers, 70-71).

63. For a social account of prosody's affordances, see Levine, Forms, 73-79.

64. See Williams, "Stem and Skein," 444. Parham (Green Man Hopkins, 177-86) notes of the verses on breathing how "the physicality of the rhythm" gives "a corporeal sense of human integration with, and dependence upon, the abiotic environment" (182). For further comments on rhythm as vital to Hopkins's ecological sensibility, see Parham, Green Man Hopkins, 153, 158-63; and Brown, Hopkins' Idealism, 300-301.

65. See M. Martin, Rise and Fall, 48-78; and Rudy, Electric Meters, 127-36.

66. Williams, "Stem and Skein," 426.

67. Bump, "Hopkins," 230, 232 (similarly contrasting "Pied Beauty" with "Spelt from Sibyl's Leaves"; see 241).

68. These late poems have also been read along thermodynamic lines: see Beer, "Helmholtz"; Brown, Hopkins' Idealism, 187-237; Nixon, "Death blots black out"; and Banfield, "Darwinism." For a wider account of Victorian thermodynamics in ecological terms, especially in urban contexts, see MacDuffie, Victorian Literature, 25-86.

69. If this moment "engulfs humanity in a vaster system, physical or metaphysical," I argue elsewhere, "it nonetheless retains human "marks' in formal and metrical patterns" (Williams, "Stem and Skein," 441).

70. On poetry and elegy in relation to ecological crisis, for example, see Morton, "Dark Ecology"; and Ronda, "Mourning and Melancholia." For a critical account of affective and generic responses to the Anthropocene, see Heise, Imagining Extinction, 32-50, 62-78.

71. Gibson notes that humans have "changed the shapes and substances of [the] environment" to "change what it affords" us but thinks we cannot entirely "alter the fact of earth, air, and water" (Ecological, 130).

\section{Works Cited}

Adorno, Theodor W. Minima Moralia: Reflections from Damaged Life. Translated by E. F. N. Jephcott. London: Verso, 1978. 
Alaimo, Stacy. Bodily Natures: Science, Environment, and the Material Self. Bloomington: Indiana University Press, 2010.

Anderson, Katharine. "Looking at the Sky: The Visual Context of Victorian Meteorology." British Journal for the History of Science 36, no. 3 (2003): 301-32.

Banfield, Marie. "Darwinism, Doxology, and Energy Physics: The New Sciences, the Poetry and the Poetics of Gerard Manley Hopkins." Victorian Poetry 45, no. 2 (2007): 175-94.

Beer, Gillian. "Helmholtz, Tyndall, Gerard Manley Hopkins: Leaps of the Prepared Imagination." Comparative Criticism 13 (1991): 117-45.

Bohm, Arnd. "William Cowper's 'The Poplar-Field' and Hopkins' 'Binsey Poplars': The Politics of Pastoral." Hopkins Quarterly 30, nos. 1-2 (2003): 45-58.

Brown, Daniel. Hopkins' Idealism: Philosophy, Physics, Poetry. Oxford: Clarendon, 1997.

Bump, Jerome. "Hopkins, the Humanities, and the Environment." Georgia Review 28, no. 2 (1974): 227-44.

Cave, Terence. Thinking with Literature: Towards a Cognitive Criticism. Oxford: Oxford University Press, 2016.

Costantini, Mariaconcetta. “'Strokes of Havoc': Tree-Felling and the Poetic Tradition of Ecocriticism in Manley Hopkins and Gerard Manley Hopkins.” Victorian Poetry 46, no. 4 (2008): 487-510.

Cotter, James F. Inscape: The Christology and Poetry of Gerard Manley Hopkins. Pittsburgh: University of Pittsburgh Press, 1972.

—. "The Inshape of Inscape." Victorian Poetry 42, no. 2 (2004): 195-200.

Crary, Jonathan. Techniques of the Observer: On Vision and Modernity in the Nineteenth Century. Cambridge, Mass.: MIT Press, 1990.

Darrigol, Olivier. A History of Optics: From Greek Antiquity to the Nineteenth Century. Oxford: Oxford University Press, 2012.

Day, Brian J. "Hopkins' Spiritual Ecology in 'Binsey Poplars." Victorian Poetry 42, no. 2 (2004): 181-93.

Dunleavy, Hannah. "The Naked Eye': Vision and Risk in the Work of Gerard Manley Hopkins." PhD diss., University of York, 2009.

Flint, Kate. The Victorians and the Visual Imagination. Cambridge: Cambridge University Press, 2000.

Gardner, W. H. Gerard Manley Hopkins (1844-1889): A Study of Poetic Idiosyncrasy in Relation to Poetic Tradition. 2 vols. London: Secker and Warburg, 1944, 1949.

Gibson, J. J. The Ecological Approach to Visual Perception. Hillsdale: Lawrence Erlbaum, 1986.

Gombrich, E. H. "The Sky Is the Limit: The Vault of Heaven and Pictorial Vision." In Perception: Essays in Honor of J. J. Gibson, edited by Robert B. MacLeod and Herbert L. Pick Jr., 84-94. Ithaca: Cornell University Press, 1974.

Heise, Ursula K. Imagining Extinction: The Cultural Meanings of Endangered Species. Chicago: University of Chicago Press, 2016.

Helsinger, Elizabeth K. Rural Scenes and National Representation: Britain, 1815-1850. Princeton: Princeton University Press, 1997.

Hensley, Nathan K., and Philip Steer, eds. Ecological Form: System and Aesthetics in the Age of Empire. New York: Fordham University Press, 2018. 
Heuser, Alan. The Shaping Vision of Gerard Manley Hopkins. London: Oxford University Press, 1958.

Hopkins, Gerard Manley. Correspondence, 1852-1881. Edited by R. K. R. Thornton and Catherine Phillips. 2 vols. Oxford: Oxford University Press, 2013.

—. Diaries, Journals, and Notebooks. Edited by Lesley Higgins. Oxford: Oxford University Press, 2015.

- Oxford Essays and Notes. Edited by Lesley Higgins. Oxford: Oxford University Press, 2006.

- The Poetical Works of Gerard Manley Hopkins. Edited by Norman H. MacKenzie. 4th ed. Oxford: Oxford University Press, 1990.

- The Sermons and Devotional Writings of Gerard Manley Hopkins. Edited by Christopher Devlin, SJ. London: Oxford University Press, 1959.

Hutchison, Hazel. "Eye Rhyme: Visual Experience and the Poetics of Gerard Manley Hopkins." Victorian Poetry 49, no. 2 (2011): 217-33.

Ingold, Tim. Being Alive: Essays on Movement, Knowledge, and Description. London: Routledge, 2011.

Jago, James. Entoptics, with Its Use in Physiology and Medicine. London: James Churchill, 1864.

Joule, James Prescott. "On Shooting Stars." London, Edinburgh, and Dublin Philosophical Magazine and Journal of Science 32 (1848): 349-51.

Joyce, James. Ulysses. Edited by Hans Walter Gabler with Wolfhard Steppe and Claus Melchior. New York: Vintage, 1993.

Kitcher, Philip. The Nature of Mathematical Knowledge. New York: Oxford University Press, 1983.

Kramnick, Jonathan. "An Aesthetics and Ecology of Presence." European Romantic Review 26, no. 3 (2015): 315-27.

Levine, Caroline. Forms: Whole, Rhythm, Hierarchy, Network. Princeton: Princeton University Press, 2015.

Lightman, Bernard V. Victorian Popularizers of Science: Designing Nature for New Audiences. Chicago: University of Chicago Press, 2007.

MacDuffie, Allen. Victorian Literature, Energy, and the Ecological Imagination. Cambridge: Cambridge University Press, 2014.

MacKenzie, Norman H. Excursions in Hopkins. Philadelphia: Saint Joseph's University Press, 2008.

Marsden, Kenneth. The Poems of Thomas Hardy: A Critical Introduction. New York: Oxford University Press, 1969.

Martin, Meredith. The Rise and Fall of Meter: Poetry and English National Culture, 18601930. Princeton: Princeton University Press, 2012.

Martin, Robert Bernard. Gerard Manley Hopkins: A Very Private Life. London: HarperCollins, 1991.

Miller, Elizabeth Carolyn. "Dendrography and Ecological Realism." Victorian Studies 58, no. 4 (2016): 696-718.

Morris, William. The Defence of Guenevere, and Other Poems. Edited by Margaret Lourie. New York: Garland, 1981. 
Morton, Timothy. "The Dark Ecology of Elegy." In The Oxford Handbook of the Elegy, edited by Karen Weisman, 251-71. Oxford: Oxford University Press, 2010.

Nixon, Jude V. “'Death blots black out': Thermodynamics and the Poetry of Gerard Manley Hopkins.” Victorian Poetry 40, no. 2 (2002): 131-56.

_ _ "Fathering Graces at Hampstead: Manley Hopkins' 'The Old Trees' and Gerard Manley Hopkins' 'Binsey Poplars." Victorian Poetry 44, no. 2 (2006): 191-211.

— . "'Sweet especial rural scene': Revisiting Binsey.” Hopkins Quarterly 16, nos. 12 (1989): 39-60.

Parham, John. Green Man Hopkins: Poetry and the Victorian Ecological Imagination. Amsterdam: Rodopi, 2010.

Pesic, Peter. Sky in a Bottle. Cambridge, Mass.: MIT Press, 2005.

Pfau, Thomas. "Rethinking the Image: With Some Reflections on G. M. Hopkins." Yearbook of Comparative Literature 57 (2011): 117-47.

Phillips, Catherine. Gerard Manley Hopkins and the Victorian Visual World. Oxford: Oxford University Press, 2007.

Ronda, Margaret. "Mourning and Melancholia in the Anthropocene." Post45, 10 June 2013, http://post45.research.yale.edu/2013/06/mourning-and-melancholia-in-the-anthropocene.

Rudy, Jason R. Electric Meters: Victorian Physiological Poetics. Athens: Ohio University Press, 2009.

Smith, A. Mark. From Sight to Light: The Passage from Ancient to Modern Optics. Chicago: University of Chicago Press, 2015.

Sobolev, Dennis. “Inscape Revisited.” English 51, no. 201 (2002): 219-34.

Strutt, John William [Lord Rayleigh]. Scientific Papers. 6 vols. Cambridge: Cambridge University Press, 1899-1920.

Taylor, Jesse Oak. The Sky of Our Manufacture: The London Fog in British Fiction from Dickens to Woolf. Charlottesville: University of Virginia Press, 2016.

Thornton, R. K. R. "Sentimental Ecology, John Clare, Gerard Manley Hopkins and Trees: A Note." John Clare Society Journal 31 (2012): 43-50.

—, ed. All My Eyes See: The Visual World of Gerard Manley Hopkins. Sunderland: Coelfrith, 1975.

Tyndall, John. "On the Blue Colour of the Sky, the Polarization of Skylight, and on the Polarization of Light by Cloudy Matter Generally." Philosophical Magazine 37 (1869): 384-94.

- Six Lectures on Light. London: Longmans, Green, 1873.

Williams, Daniel. "Stem and Skein: Order and Evolution in Hopkins." Victorian Poetry 53, no. 4 (2015): 423-54.

Willis, Martin. Vision, Science, and Literature, 1870-1920: Ocular Horizons. London: Pickering and Chatto, 2011.

Zaniello, Tom. Hopkins in the Age of Darwin. Iowa City: University of Iowa Press, 1988.

—. "The Sources of Hopkins' Inscape: Epistemology at Oxford, 1864-1868." Victorian Newsletter 52 (1977): 18-24.

—. "The Spectacular English Sunsets of the 1880s." In Victorian Science and Victorian Values: Literary Perspectives, edited by James Paradis and Thomas Postlewait, 247-67. New York: Academy of Sciences, 1981. 